Research Article

\title{
A Meta-Analysis of the Effects of Realistic Mathematics Education- based Teaching on Mathematical Achievement of Students in Turkey
}

\author{
Sedat TURGUT *1 (iD) \\ ${ }^{1}$ Bartın University, Turkey, sedatturgut42@gmail.com \\ ${ }^{*}$ Corresponding Author: sedatturgut42@gmail.com
}

\begin{tabular}{|c|c|}
\hline Article Info & Abstract \\
\hline $\begin{array}{ll}\text { Received: } & 22 \text { December } 2020 \\
\text { Accepted: } & 25 \text { March } 2021\end{array}$ & $\begin{array}{l}\text { The aim of the current study is to determine the effect of realistic } \\
\text { mathematics education-based teaching on students' mathematics } \\
\text { achievement. For this purpose, a meta-analysis method, which allows } \\
\text { combining the results of a series of studies on a subject, was used in the } \\
\text { study. A total of } 40 \text { scientific publications, } 27 \text { thesis and } 13 \text { articles, } \\
\text { which are suitable for the research problem, were included in the } \\
\text { sample of the study. The publications conducted on mathematics } \\
\text { achievement in } 2020 \text { and earlier in Turkey were used in the study. }\end{array}$ \\
\hline $\begin{array}{l}\text { Keywords: Achievement, effect size, } \\
\text { mathematics education, meta- } \\
\text { analysis, realistic mathematics } \\
\text { education }\end{array}$ & $\begin{array}{l}\text { Process effectiveness method of meta-analysis was employed in the } \\
\text { analysis of data and Hedges's g was used in the calculation of effect } \\
\text { size of the study. In determination of the publication bias of the studies } \\
\text { included in the meta-analysis, the funnel plot and Rosenthal's Fail-Safe }\end{array}$ \\
\hline doi $10.18009 /$ jcer.844906 & $\begin{array}{l}\text { N-FSN statistics were examined together. In order to determine } \\
\text { whether the distribution of the effect sizes is homogenous or not, the } \\
\text { results of Q statistic were investigated. As a result, the effect sizes are }\end{array}$ \\
\hline Publication Language: English & $\begin{array}{l}\text { homogeneously distributed. Therefore, fixed effect model was used. As } \\
\text { stated in the fixed effects model, the overall effect size value is } 0.760 \\
\text { with a } 0.041 \text { level of standard error. As a result of the study, the effect } \\
\text { of teaching activities based on realistic mathematics education on } \\
\text { mathematical achievement is at a positive medium level. }\end{array}$ \\
\hline
\end{tabular}

open $\bigcirc$ access $\square$ CrossMark (C)

To cite this article: Turgut, S. (2021). A meta-analysis of the effects of realistic mathematics education-based teaching on mathematical achievement of students in Turkey. Journal of Computer and Education Research, 9 (17), 300-326. DOI: 10.18009/jcer.844906

\section{Introduction}

Considering the fact that mathematics is a part of many areas including daily and academic lives, and careers of individuals, it can be stated that those who are good at mathematics will be successful at life and get opportunities in life (National Council of Teachers of Mathematics [NCTM], 2000; Organization for Economic Co-operation and Development [OECD], 2013). Nevertheless, it is well known that many individuals show the attitude that mathematics is not their cup of tea (Di Martino \& Zan, 2011). One of the reasons why individuals have such an attitude may be related to how they learn mathematics. NCTM state that all students need to attain mathematical knowledge, and necessary support 
and opportunities must be provided for this aim (NCTM, 2000). Consequently, understanding mathematics is closely related to having a teaching process with good quality. It can also be stated that one of the requirements of the teaching process with good quality is to make use of different approaches. Using methods and techniques which are based on different approaches have a positive effect on the learning process of students (Piht \& Eisenschmidt, 2008; Soric \& Palekcic, 2009). It can be stated that this situation is one of the points to be taken into consideration in the teaching process.

\section{Realistic Mathematics Education}

One of the approaches that shape mathematics teaching is realistic mathematics education (RME). RME is a mathematics teaching theory which was created by Dutch mathematician Hans Freudenthal and developed further by Freudenthal Institute (Treffers, 1993). RME emerged as an innovative approach against traditional mathematics teaching (De Corte, 2000). Traditional mathematics teaching can be defined as a teaching process in which mathematics is presented as a ready-made standard system and taught through mechanical means (Van den Heuvel-Panhuizen, 2001). As for Freudenthal (1973), mathematics can be defined as human activity. Freudenthal (1973) asserted that mathematics is not a subject or knowledge to be conveyed. Mathematics starts with real-life problems and formal mathematics is reached through mathematization of the real-life problems (Gravemeijer \& Terwel, 2000). The term real expresses real-life situations from an experimental point of view. Problems do need not include only real-life situations; they need to be in a format which the students may experience through actions (Gravemeijer \& Doorman, 1999).

Teaching of mathematics needs to be closely related to reality and students' experiences (Van den Heuvel-Panhuizen, 2001). RME advocates that students should be given opportunities that let them rediscover mathematics. The experience of teaching mathematics needs to become fun and beneficial for the students; therefore, a connection must be made between the real world and mathematics (Van den Heuvel-Panhuizen, 2001; 2003). When children realize how mathematics can be used in real life, they will learn better. The informal knowledge that the children possess may be effective in developing their formal knowledge (Treffers, 1991). Students rediscover mathematics while solving real-life problems. Therefore, the teachers relate mathematics teaching with the existing knowledge 
of the students. Mathematics teaching should be organized as a rediscovering process in a manner that resembles the experience of the process of how mathematicians discovered mathematics (Freudenthal, 1991).

\section{Mathematization}

Mathematics is an activity of looking for and solving problems and organizing the solution of a problem. This activity may be a real problem that needs to be organized and solved in accordance with mathematical patterns (Freudenthal, 1971). This organizational activity is called mathematization (Gravemeijer, 1994; Treffers, 1991). Mathematization is a key process in mathematics teaching since dealing with mathematics teaches students to deal with daily life situations with a mathematical approach. When the students deal with mathematical knowledge with a mathematical perspective, they will have a true understanding of concepts and the implementation of these concepts. According to RME, the students need to reach mathematical knowledge by discovering through experiences (Gravemeijer \& Doorman, 1999).

Treffers (1987) takes on the mathematization in two processes, namely, horizontal process and vertical process. The students use mathematical tools in organizing problems regarding real-life situations in the horizontal mathematization process (Gravemeijer \& Doorman, 1999; Van den Heuvel-Panhuizen, 2003; Van den Heuvel-Panhuizen \& Drijvers, 2014). The horizontal mathematization process enables students to reach mathematical symbols through their real-life situations (Freudenthal, 1991). Expressing a real-life problem in a mathematical manner is a product of the horizontal mathematization process. On the other hand, the vertical mathematization process is formulizing mathematics in various ways through mathematical rules and reorganizing the mathematical system (Van den Heuvel-Panhuizen, 2003; Van den Heuvel-Panhuizen \& Drijvers, 2014). Transforming a reallife problem into a mathematical problem is a product of the vertical mathematization process. Since abstract mathematical symbols are used in this process, it will occur more often in a classroom environment (Gravemeijer \& Terwel, 2000). In the vertical mathematization process, the students can make mathematical formulizations of relationships, make explanations with various examples, and reach conclusions. 
Freudenthal (1991) stated that horizontal mathematization is going from realistic to symbolic situations, and vertical mathematization is moving through symbolic situations; however, no strict distinction between the two. The most significant way to describe the distinction between horizontal and vertical mathematics is to give examples at various levels (Freudenthal, 1991). Transferring a realistic problem to a mathematical problem, exploring patterns and relationships, schematizing, formulizing in various methods, and visualization activities are examples of horizontal mathematization. Representing relationships with formulas, developing models, integrating various methods, and generalization activities are among the examples for vertical mathematization (De Lange, 1987). Therefore, vertical and horizontal mathematization processes are closely related to each other. There is no superior process between the two; only, emphasizing real-life situations may put the vertical mathematizing process in the background (Van den Heuvel-Panhuizen \& Drijvers, 2014). Based on these facts, vertical and horizontal mathematizing processes need to be considered hand-in-hand within the process of mathematics teaching.

Principles of Realistic Mathematics Education

RME has a dynamic structure; yet, it has fundamental principles. These principles, which were stated firstly by Treffers (1978) and has gone through reformations in time, and explained by Van den Heuvel-Panhuizen and Drijvers (2014) are as follows:

Activity principle: The students are active participants in the learning process. Mathematics is best learned by dealing with practice.

Reality principle: Mathematics teaching should begin with meaningful problem situations. Students develop mathematical understanding and tools which they produced while solving real-life problems. Teaching does not start with abstract and definitions, it starts with a contextual problem which requires mathematical organizations.

Level principle: Students go through various levels of comprehension while learning mathematics. In this process, models are important in filling in the blanks between informal and formal mathematics.

Intertwinement principle: Learning mathematics is a social activity. The students can share their strategies and discoveries through in-class discussions and group activities. Thus, 
they may acquire ideas that enable them to develop strategies and reach a higher level of comprehension.

Guidance principle: The teachers have a proactive role in the learning process of the students.

Teachers need to consider the aforementioned principles while preparing teaching activities based on RME. In RME, mathematical knowledge must be constructed or reconstructed by the student. Under no circumstance, mathematical knowledge is readily available and transferred in a top-down manner. Even in a perfect lesson, the mathematical knowledge offered to students can only become meaningful through actively reconstructing the knowledge by every student. Students must re-discover mathematics by starting from fundamental experiences under the appropriate guidance (Freudenthal, 1971). Teaching must start with meaningful real-life problems rather than rules and abstract concepts. The role of teaching must not be directly conveying mathematical knowledge; but, guiding the students and expose their theoretical knowledge (Gravemeijer \& Doorman, 1999; Van den Heuvel-Panhuizen, 2001, 2003).

\section{The Present Study}

When the literature is reviewed, a great deal of research can be found on the effect of activities conducted based on RME on mathematics teaching and learning on an international level (Fauzan, 2002; Gravemeijer \& Doorman, 1999; Le, 2006; Sembiring, Hadi, \& Dolk, 2008) as well as in Turkey (Demir, 2017; Korkmaz, 2017; Taş, 2018; Yorulmaz, 2018). In these studies which were conducted independently from each other, the teaching activities implemented based on RME, the effect of different variables such as sample size, level of education, treatment duration, and field of study were examined. These studies also have various limitations and due to this reason, conclusions of these studies may differ or show similarities to each other. Bringing together the research findings and creating a synthesis will lead the way to draw a conclusion and making generalizations of the results. Within this context, meta-analysis studies show great significance. Meta-analysis allows a coherent process of gathering and interpreting the results of individual studies conducted independently from each other (Cohen, Manion, \& Morrison, 2007). When the literature is examined, it can be seen that a study by Kaplan, Duran, Doruk, and Öztürk (2015) brings 
together 12 dissertations that examine the effectiveness of teaching based on RME in Turkey. In their study, the overall effect size regarding the individual studies conducted between 2007-2014 was calculated. Another study by Özdemir (2020), brings together 23 studies that examine the effectiveness of teaching based on RME in Turkey. In the mentioned study the overall effect size regarding the individual studies conducted between 2007-2019 was calculated. In a meta-analysis study conducted by Çelik (2013) examining the effect of alternative learning methods, the overall effect size of 4 dissertations which examined teaching based on RME 2007-2011 was calculated.

Considering years that these studies were published and the number of studies they took in the analysis, it can be stated that there is a need for a meta-analysis study which takes into consideration more recent studies and summarized the current situation on the matter. In this respect, this study aims to determine the effects of RME-based teaching on mathematical achievement of the students through meta-analysis. The studies in which the effects of RME-based teaching are measured by standardized achievement tests (knowledge and abilities towards the learning outcomes of mathematics are tested in writing and measured on a standard score) were focused in the study. Moreover, different from the studies of Çelik (2013), Kaplan et al. (2015) and Özdemir (2020), the present study is to investigate if there is a significant difference in the effect sizes of studies included in the meta-analysis in terms of field of study, level of education, size of sampling, and treatment duration regarding RME-based teaching.

In line with this aim, the following research questions were sought to be answered:

1. What is the overall effect of mathematics lessons based on RME on students' mathematics achievement?

2. Does the effect size of mathematics lessons taught based on RME on students' mathematics achievement differ according to the field of study?

3. Does the effect size of mathematics lessons taught based on RME on students' mathematics achievement differ according to the level of education?

4. Does the effect size of mathematics lessons taught based on RME on students' mathematics achievement differ according to the sample size? 
5. Does the effect size of mathematics lessons taught based on RME on students' mathematics achievement differ according to the treatment duration?

\section{Method}

Research Design

Meta-analysis method was implemented in this study. A meta-analysis provides a general assessment through the analysis of quantitative results obtained from individual studies on a specific topic (Glass, 1976; Lipsey \& Wilson, 2001). Through a meta-analysis, the current state of the related subject can be discovered. Effect size is used in the assessment of the findings of the meta-analysis study (Mertens, 2010). The value of the effect size reflects the relationship between two variables (Borenstein, Hedges, Higgins, \& Rothstein, 2009; Ellis, 2010). In other words, it represents the size of the relationship between variables. The effect size is a common metric for studies that are included in effect size meta-analysis and it provides the opportunity of interpreting the statistically analyzed studies through the same measurement. There are certain steps to be followed in a meta-analysis study. Firstly, the problem is identified; and then the literature related to the literature is reviewed. The studies obtained as a result of the study are coded in specified criteria. Finally, the statistical analyses of the studies are conducted, and a conclusion is drawn (Pigott, 2012; Sánchez-Meca \& Marín-Martínez, 2010). This study made use of the aforementioned steps.

\section{Data Collection}

The data of this study were collected within October 2020. The data source is constituted by studies that examined the effect of RME-based teaching on students' mathematical achievement in Turkey. In order to reach the studies, "realistic mathematics education, RME" keywords were searched on indexes such as Web of Science, Education Resources Information Center (ERIC), EBSCOhost, Scopus, Council of Higher Education Thesis Center, TR Index, and Google Scholar. A total of 96 master's thesis, doctoral dissertations and articles were reached as a result of the scanning. It was seen that some of the articles were reproduced from dissertations; instead of thesis, these articles were included in the meta-analysis, and the rest of the studies were picked in accordance with the following criteria:

1. The studies must be conducted in Turkey. 
2. The studies must be conducted in 2020 or earlier.

3. The studies must have an experimental research design (experimental and control group design with pre-test and post-test).

4. There must not be a statistically significant difference between the achievement scores of experimental and control groups as determined by the results of pre-test (groups must be homogeneous in terms of achievement).

5. Experimental groups must be taught based on RME and the control groups must be taught based on the mathematics program determined by the national curriculum for the specific year.

6. Publication language must beTurkish or English.

7. The studies must be open to access in indexes such as Web of Science, ERIC, EBSCOhost, Scopus, Cohe Thesis Center, TR Index, and Google Scholar.

8. The studies must include reliability and validity statements regarding the data collection tools (achievement tests).

9. The studies must include statistical values (pre-test and post-test achievement scores for experimental and control groups, sampling size, standard deviation values, $p$-values etc.) in order to calculate the effect size.

In line with the specified criteria, 40 studies were included in the meta-analysis. Two of these studies used two different achievement tests and one study included one experimental and two control groups. For these reasons, the effect sizes in these studies were calculated and presented in forest table with labels a and b next to the year of the studies. As a result, 43 effect sizes were calculated regarding 40 studies.

\section{Data Coding}

A feature to be encoded in meta-analysis studies may have a structure that will affect the effect sizes of the research (Ellis, 2010). For this reason, a coding has been made that can transform the data in these studies into categorical variables by using the studies that meet the inclusion criteria of the research (Lipsey \& Wilson, 2001). Thus, the characteristics of the study were determined. The coding form of the study has a structure that is general enough to include all studies related to the effect of Realistic Mathematics Education-based teaching on mathematics achievement, but enough to determine research differences. A coding form 
was prepared by the researcher by taking into consideration the specified criteria of inclusion. The information included in the forms are: title of the study, year, author, type, sample size (experimental-control), level of education, field of study of the implemented teaching activities, treatment duration, reliability and validity statements regarding the data collection tools (present-absent), and arithmetic mean and standard deviation of the measurements at the end of the teaching activity. The information which was to be included in the study was coded on the form by the researcher. Three weeks after the initial coding, the forms were recoded by the researcher using the same forms. The forms were compared after the two processes and no difference was observed between the two forms. Through this procedure, an error-free statistical analysis of the data gathered from the studies was targeted. In Table 1, the descriptive statistics regarding the studies included in the metaanalysis which investigated the effects of RME-based on mathematical achievement in Turkey are presented.

Table 1. The studies included in the meta-analysis which investigated the effects of RME-based teaching on students' mathematical achievement in Turkey

\begin{tabular}{|c|c|c|c|}
\hline & & Frequency & Percentage (\%) \\
\hline \multirow{3}{*}{ Type of Study } & Research Article & 13 & $32.5 \%$ \\
\hline & Master's Thesis & 24 & $60 \%$ \\
\hline & Doctoral Dissertation & 3 & $7.5 \%$ \\
\hline \multirow{3}{*}{ Year of the Study } & $2006-2010$ & 5 & $12.5 \%$ \\
\hline & 2011-2015 & 13 & $32.5 \%$ \\
\hline & 2016-2020 & 22 & $55 \%$ \\
\hline \multirow{6}{*}{ Sample Size ${ }^{*}$} & 1-15 participants & 2 & $5 \%$ \\
\hline & $16-30$ participants & 24 & $60 \%$ \\
\hline & 31-45 participants & 11 & $27.5 \%$ \\
\hline & 46-60 participants & 2 & $5 \%$ \\
\hline & $61-75$ participants & - & - \\
\hline & 76-90 participants & 1 & $2.5 \%$ \\
\hline \multirow{3}{*}{ Level of Education } & Primary School & 12 & $30 \%$ \\
\hline & Middle School & 24 & $60 \%$ \\
\hline & High School & 4 & $10 \%$ \\
\hline \multirow{2}{*}{ Field of Study ${ }^{* *}$} & Mathematics & 32 & $80 \%$ \\
\hline & Geometry & 8 & $20 \%$ \\
\hline \multirow{9}{*}{$\begin{array}{l}\text { Duration of the } \\
\text { Treatment }\end{array}$} & $1-5$ hours & 4 & $10 \%$ \\
\hline & 6-10 hours & 10 & $25 \%$ \\
\hline & 11-15 hours & 7 & $17.5 \%$ \\
\hline & 16-20 hours & 9 & $22.5 \%$ \\
\hline & 21-25 hours & - & - \\
\hline & 26-30 hours & 1 & $2.5 \%$ \\
\hline & 31-35 hours & - & - \\
\hline & $36-40$ hours & 2 & $5 \%$ \\
\hline & Not specified in hours & 7 & $17.5 \%$ \\
\hline Total & & 40 & $\% 100$ \\
\hline
\end{tabular}


*Only the experimental groups. ${ }^{*}$ Mathematics field includes topics such as numbers and operations, fractions, sets, probability and algebraic expressions. The geometry field includes topics such as transformation geometry, polygons, geometric shapes, length, area and volume.

Table 1 reveals that $13(32.5 \%)$ of the studies are articles, $24(60 \%)$ of the studies are master's thesis, and 3 (7.5\%) of the studies are doctoral dissertations. Before 2006, there was no experimental study on this subject. Most studies were conducted between 2016-2020 (22 studies, 55\%). In terms of the sample size, most of the studies included between 16-30 participants (24 studies, $60 \%$ ). In terms of the level of education, most of the studies included middle school (24 studies, 60\%), least number of the studies included high school level (4 studies, 10\%). There was not meet any study at undergraduate level. 32 (80) of the studies were related to mathematics, and $8(20 \%)$ of the studies were related to geometry. While $6-10$ hours of implementation (10 studies, 25\%) and 16-20 hours of implementation (9 studies, $22.5 \%)$ were most prevalent, $7(17.5 \%)$ of the studies did not specify the hour of implementation.

\section{Data Analysis}

While calculating the effect size of studies through meta-analysis, the fixed-effects model and random-effects model were used (Borenstein et al., 2009). In the fixed-effects model, the effect sizes of the studies to be included in the meta-analysis are assumed to be fixed; therefore, the effect sizes and standard deviations are taken as zero. In the randomeffects model, the effect sizes of the studies to be included in the meta-analysis are assumed to differ in every study, and the effect sizes and standard deviations are assumed to be different from zero (Ellis, 2010). The distribution of the effect size determines which one of these two models are to be used in a meta-analysis study. For this purpose, meta-analysis studies make use of $Q$ value. $Q$ value in statistics is used with the purpose of testing the null hypothesis that the meta-analysis studies which were analyzed through chi-square distribution share a common effect size. If the $Q$ value is smaller than the equivalent value from the table of chi-square $\left(\chi^{2}\right)$ in terms of the degree of freedom (df) and level of significance ( $p$-value), the homogeneity is established (Borenstein et al., 2009). If the distribution is homogeneous, the fixed-effects model is used; and, if it is heterogeneous, the random-effects model is used (Ellis, 2010). However, studies with extremely small or large effects, in other words, individual studies that differ significantly from the overall effect, 
affect the Q statistic result (Harrer, Cuijpers, Furukawa, \& Ebert, 2019). Therefore, outliers should be detected. Outliers have a dramatic inflationary effect on the variance. Correlations that are so far out of the distribution that they are clearly outliers so they could be thrown out (Hunter and Schmidt, 2004). In order to detect such outliers in the data set, all studies were examined according to the following conditions:

For which the upper bound of the 95\% confidence interval is lower than the lower bound of the pooled effect confidence interval (i.e., extremely small effects), and for which the lower bound of the $95 \%$ confidence interval is higher than the upper bound of the pooled effect confidence interval (i.e., extremely large effects) (Harrer et al., 2019, Searching for extreme effect sizes (outliers) section, para. 2).

As a result, individual studies with extremely small or large effects were excluded from the analysis process (9 studies were excluded).

While calculating the effect sizes, Hedges'g, which determines the intergroup pooled and standard means were used, and the confidence level was accepted as $95 \%$ in the calculations. In interpreting the effect size, “0-0.20 level was accepted as weak, 0.21-0.50 was accepted as small, 0.51-1.00 level was accepted as medium, and a level greater than 1 was accepted as large" (Cohen et al., 2007, p. 521).

In the determination of the publication bias of the studies included in the metaanalysis, the funnel plot and Rosenthal's Fail-Safe N-FSN statistics were examined together. If the effect sizes of the studies in the funnel plot were symmetrically distributed on the overall effect size, this indicates that there is no publication bias (Borenstein et al., 2009). The value obtains as a result of Rosenthal's fail-safe $\mathrm{N}$ indicates the number of studies to be included in order to zero out the calculated effect in the meta-analysis (Borenstein et al., 2009). The FSN value being large in proportion to the studies examined indicates that the results are resistant to publication bias (Rosenthal, 1991). Therefore, it can be stated that as FSN value rises, the reliability of the results increases (Ellis, 2010). This study also made use of $\mathrm{N} /(5 \mathrm{k}+10)$ ( $\mathrm{k}$ referring to the number of studies included in the meta-analysis) formula which was suggested by Mullen, Muellerleile, and Bryant (2001) based on Rosenthal's failsafe N. According to this formula, if the value to be obtained is greater than 1, the results are resistant enough against publication bias. 
This study made use of Comprehensive Meta-Analysis (CMA) software in obtaining the effect sizes, moderator analyses, publication bias analyses, funnel plot, and forest plot. And MetaWin statistics program was used to examine the normal distribution of effect sizes. By making use of the interface that CMA offers, the format which enables values such as the sample size $(N)$, mean $(\bar{X})$, standard deviation $(S D)$, and $p$ and $t$ values were used. In this study, the field of study, education level, sample size, and treatment duration were determined as the moderators.

\section{Findings}

In order to determine whether it is convenient to combine the effect sizes of the studies with meta-analysis, the normal distribution chart was examined. Normal distribution chart is given in Figure 1.

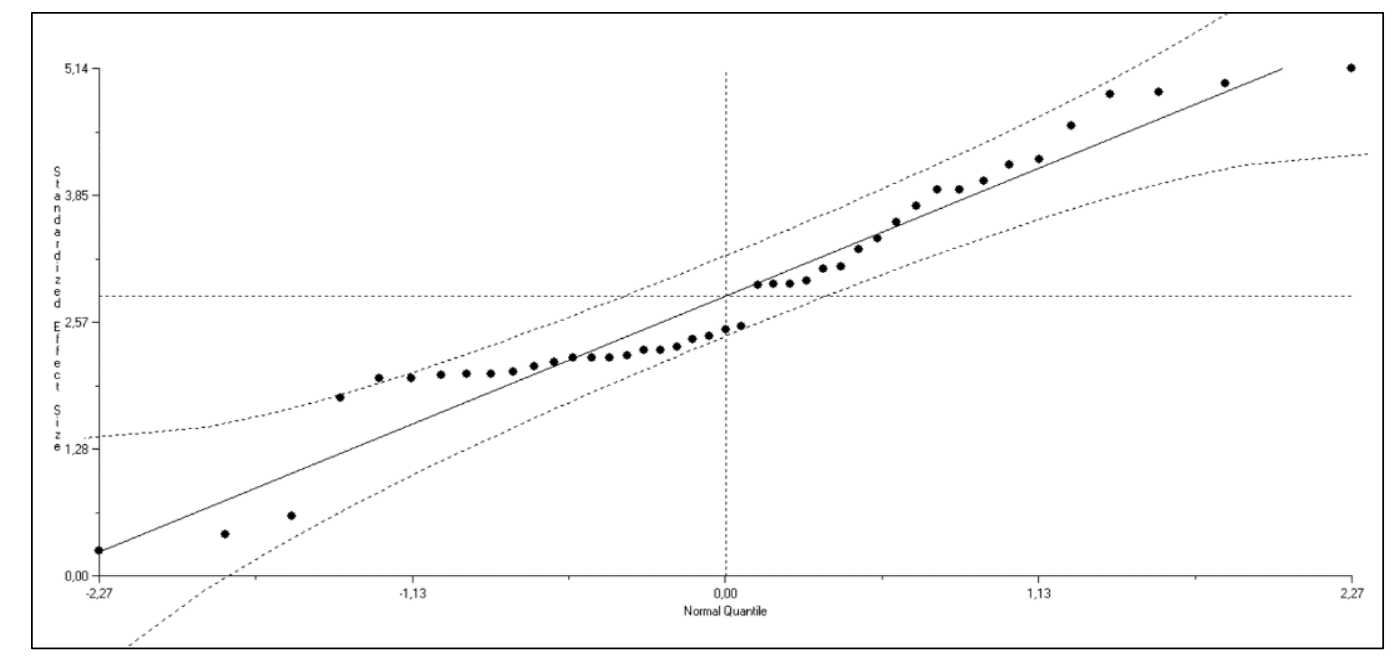

Figure 1. Normal distribution chart of effect sizes of studies included in meta-analysis.

When Figure 1 is examined, it is seen that the effect sizes of the studies are distributed around the normal distribution line and within the confidence interval shown with dashed lines. In this regard, it can be stated that the effect sizes show normal distribution and can be combined statistically with meta-analysis.

A funnel plot was examined in order to determine the publication bias of the studies. The funnel scatter plot is given in Figure 2. 


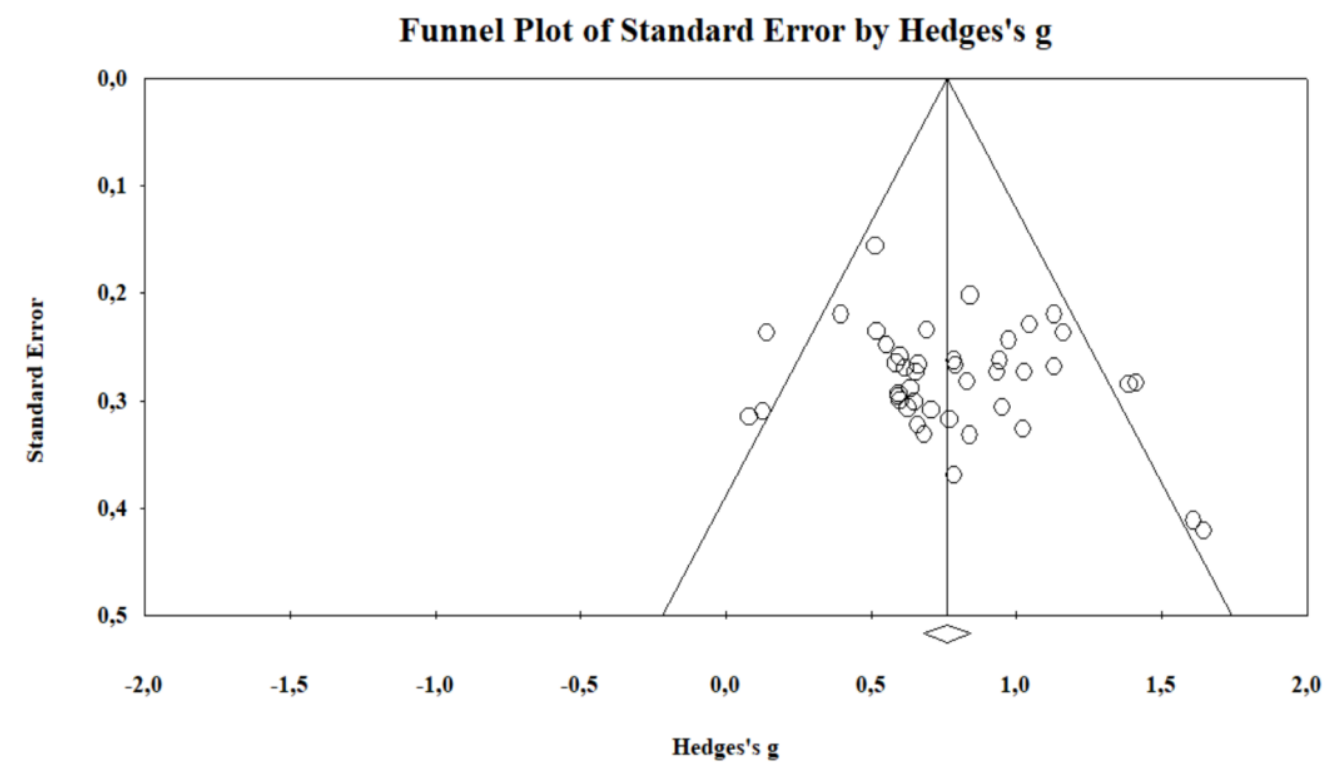

Figure 2. Funnel scatter plot regarding the publication bias of the studies included in the meta-analysis

Figure 2 reveals that the funnel plot is concentrated in the middle and scattered as symmetric around either side of the vertical line which demonstrates the effect size, except for a few studies. The fact that the effect sizes of the studies included in the study are very close to the combined effect size value in the center of gravity region, is an indication that there is no publication bias (Borenstein et al., 2009). In the funnel scatter plot, it is seen that the individual effect sizes of some studies are outside the funnel. This may be due to the excess of primary studies. Considering that more than one finding from the same study is used in a small number, it may not be said that this situation has a negative effect on publication bias. However, interpretation of a funnel scatter plot is subjective (Rothstein, Sutton, \& Borenstein, 2005). Therefore, Rosenthal's N-FSN value was also examined in determining the publication bias. Statistics regarding this value are given in Table 2.

Table 2. Results of Rosental's FSN regarding the studies included in the metaanalysis

\begin{tabular}{ll}
\hline Bias Level & \\
\hline$Z$ value for the studies examined & 18.58677 \\
\hline$p$-value for the studies examined & 0.00000 \\
\hline Alpha & 0.05 \\
\hline Direction & 2 \\
\hline$Z$ value for Alpha & 1.95996 \\
\hline Number of the studies examined & 43 \\
\hline FSN & 3825 \\
\hline
\end{tabular}


Table 2 indicates that the FSN value is 3825 . From this result, it can be stated that a total of 3825 studies with zero effect size are needed so that the effect size calculated as a result of meta-analysis is not statistically significant. In other words, in order for the findings of this meta-analysis, which consists of 43 research data, to be deemed invalid, there should be at least 3825 studies that contradict the values of the findings in the literature. When considered in Turkey reached a total of 96 relevant studies on the same subject matter will be contrasting findings of the 3825 study is not easily visible. Moreover, In addition, since the value calculated according to the $\mathrm{N} /(5 \mathrm{k}+10)$ formula $(3825[5 * 43+10]=17)$ is greater than the critical value of 1 , it shows that the studies included in the meta-analysis are sufficiently resistant to the publication bias of future studies (Mullen et al., 2001; Rosenthal, 1991).

On the other hand, in this study, both heterogeneity test was performed and graphics were used to determine whether the effect sizes were suitable for normal distribution. According to this, the results regarding the fixed effects model and random effects model of the studies included in the meta-analysis are presented in Table 3.

Table 3. Results of the studies in regard to effect models

\begin{tabular}{|c|c|c|c|c|c|c|c|c|}
\hline \multirow{3}{*}{ Model } & \multirow{3}{*}{$\begin{array}{l}\text { Overall } \\
\text { Effect } \\
\text { Size } \\
\text { Value } \\
\text { (ES) }\end{array}$} & \multirow{2}{*}{\multicolumn{2}{|c|}{$\begin{array}{l}95 \% \text { Confidence } \\
\text { Interval for } \\
\text { Effect Size }\end{array}$}} & \multirow{3}{*}{$\begin{array}{l}\text { Standard } \\
\text { Error (SE) }\end{array}$} & \multirow{3}{*}{$\begin{array}{l}\text { Degree of } \\
\text { Freedom } \\
\text { (df) }\end{array}$} & \multirow{3}{*}{$\begin{array}{l}\text { Homogeneity } \\
\text { Value }(\mathrm{Q})\end{array}$} & \multirow{3}{*}{$\begin{array}{l}\text { Chi- } \\
\text { Square } \\
\text { Table } \\
\text { Value } \\
\left(\chi^{2}\right)\end{array}$} & \multirow{3}{*}{$p$} \\
\hline & & & & & & & & \\
\hline & & $\begin{array}{l}\text { Lower } \\
\text { Limit }\end{array}$ & $\begin{array}{l}\text { Upper } \\
\text { Limit }\end{array}$ & & & & & \\
\hline Fixed & 0.760 & 0.680 & 0.840 & 0.041 & 42 & 57.615 & 58.124 & 0.055 \\
\hline Random & 0.768 & 0.672 & 0.863 & 0.049 & & & & \\
\hline
\end{tabular}

When Table 3 is examined it can be seen that the homogeneity value of the studies included in the meta-analysis is $\mathrm{Q}=57.615$ according to fixed effects model. The critical value of the degree of freedom at the $95 \%$ significance level on the chi-square table is 58.124. It can be seen that the calculated $Q$ value is smaller than the critical value in the chi-square. Moreover, the $p$-value is not significant $(p=.055>.05)$. On this basis, it can be stated that the studies included in the meta-analysis are homogeneous; therefore, while calculating the effect size of the studies, the fixed effects model was used. With regard to the fixed effects model, the calculated overall effect size is 0.760 with a standard error of 0.041 . The effect size being positive means that the process effect is in favor of the experimental group. The calculated effect value is medium, according to Cohen et al. (2007). Consequently, it can be 
stated that RME-based teaching has a positive moderate effect on students' mathematical achievement.

Forest plot demonstrating the distribution of the effect size of the studies included in the meta-analysis according to the fixed effects model is shown in Figure 3.

Meta Analysis

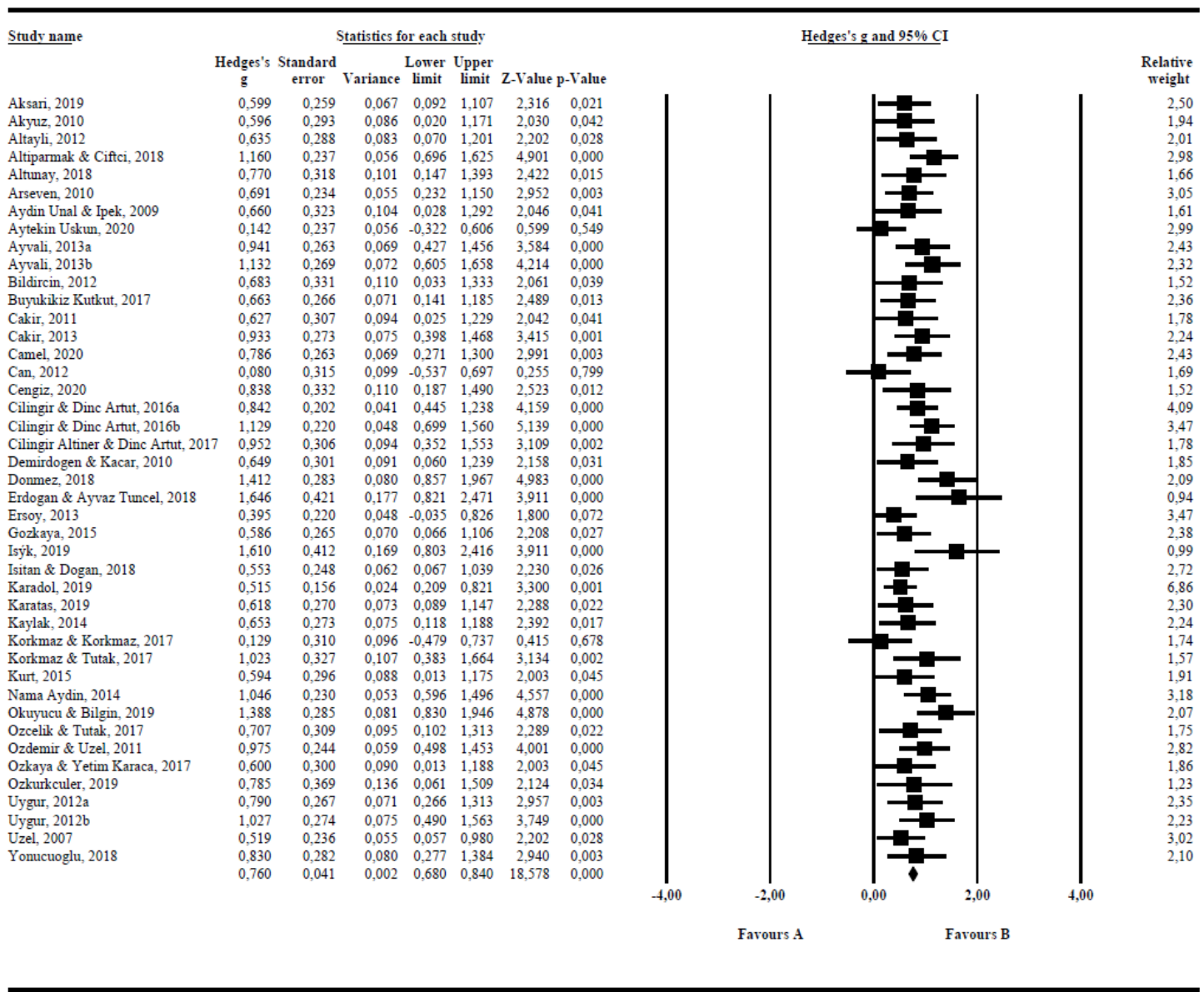

Figure 3. Forest plot regarding the effect size of the studies included in the meta-analysis according to fixed effects model

Each black dot in Figure 3 represents an effect size of a study. The lines on either side of the squares indicate the lower and upper limits in a $95 \%$ confidence interval of the calculated effect sizes. The area of the squares represents the magnitude of related study in the effect size. Moreover, some statistical values are given in the rightest column of the figure. The rhombus at the bottom represents the calculated overall effect size. When the forest plot showing the effect direction of the studies is examined, it can be said that the majority of the studies included in the study are far from the ineffectiveness line and are distributed in a balanced way between medium-wide effect level. When the effect size values 
of the studies are examined, it is determined that the highest effect size value was 1.646 and the smallest effect size value was 0.129 . The reason why the square sizes representing the effect sizes of the studies included in the study are close to each other is that the sample numbers of the experimental-control group students in the studies included in the research are close to each other. When the calculated effect size values are examined, all of them are positive. In this case, it can be said that the studies examining the effect of teaching based on realistic mathematics education on mathematics achievement are in favor of the experimental group.

Results regarding the significant difference between the effect sizes of the studies in terms of field of study (mathematics and geometry) of RME-based teaching in are shown in Table 4.

Table 4. Results regarding the effect size in terms of field of study

\begin{tabular}{|c|c|c|c|c|c|c|c|}
\hline \multirow[t]{2}{*}{ Moderator } & \multirow{2}{*}{$\begin{array}{l}\text { Intergroup } \\
\text { Homogeneity } \\
\text { Value } \\
\left(Q_{B}\right)\end{array}$} & \multirow[t]{2}{*}{$p$} & \multirow[t]{2}{*}{$\mathrm{n}$} & \multirow{2}{*}{$\begin{array}{l}\text { Overall } \\
\text { Effect Size } \\
\text { Value (ES) }\end{array}$} & \multicolumn{2}{|c|}{$\begin{array}{l}\text { \%95 Confidence } \\
\text { Interval for Effect } \\
\text { Size }\end{array}$} & \multirow{2}{*}{$\begin{array}{l}\text { Standard } \\
\text { Error (SE) }\end{array}$} \\
\hline & & & & & $\begin{array}{l}\text { Lower } \\
\text { Limit }\end{array}$ & $\begin{array}{l}\text { Upper } \\
\text { Limit }\end{array}$ & \\
\hline Field of Study ${ }^{*}$ & 0.081 & 0.777 & & & & & \\
\hline Mathematics & & & 34 & 0.753 & 0.659 & 0.847 & 0.048 \\
\hline Geometry & & & 9 & 0.779 & 0.625 & 0.933 & 0.079 \\
\hline
\end{tabular}

"Mathematics field includes topics such as numbers and operations, fractions, sets, probability and algebraic expressions. The geometry field includes topics such as transformation geometry, polygons, geometric shapes, length, area and volume.

When Table 4 is examined, it can be seen that intergroup homogeneity value $\left(Q_{в}\right)$ in terms of the field of study is 0.081 . In the chi-square table, the critical value of $95 \%$ confidence interval with 1 degree of freedom is 3.841. It is also observed that the intergroup homogeneity value is smaller than the critical value in the chi-square table $\left(Q_{B}=0.081\right.$, $p=.777>.05)$. In this regard, it can be stated that the RME-based teaching does not show a significant difference in terms of the field of study.

The results regarding the significant difference between the effect sizes of the studies in terms of the level of education (primary school, middle school, and high school) of RMEbased teaching are shown in Table 5. 
Table 5. Results regarding the effect size in terms of level of education

\begin{tabular}{|c|c|c|c|c|c|c|c|}
\hline \multirow{3}{*}{ Moderator } & \multirow{3}{*}{$\begin{array}{l}\text { Intergroup } \\
\text { Homogeneity } \\
\text { Value } \\
\left(Q_{B}\right)\end{array}$} & \multirow{3}{*}{$p$} & \multirow{3}{*}{$\mathrm{n}$} & \multirow{3}{*}{$\begin{array}{l}\text { Overall } \\
\text { Effect Size } \\
\text { Value (ES) }\end{array}$} & \multicolumn{2}{|c|}{ \%95 Confidence } & \multirow{2}{*}{$\begin{array}{l}\text { Standard } \\
\text { Error } \\
(\mathrm{SE}) \\
\end{array}$} \\
\hline & & & & & $\begin{array}{l}\text { Interval } \\
\text { Effect } S\end{array}$ & for & \\
\hline & & & & & $\begin{array}{l}\text { Lower } \\
\text { Limit }\end{array}$ & $\begin{array}{l}\text { Upper } \\
\text { Limit }\end{array}$ & \\
\hline Level of Education & 3.716 & 0.156 & & & & & \\
\hline Primary school & & & 13 & 0.787 & 0.645 & 0.929 & 0.073 \\
\hline Middle school & & & 26 & 0.715 & 0.612 & 0.818 & 0.052 \\
\hline High school & & & 4 & 1.013 & 0.719 & 1.307 & 0.150 \\
\hline
\end{tabular}

Table 5 indicates that intergroup homogeneity value $\left(\mathrm{Q}_{\mathrm{B}}\right)$ in terms of the level of education is 3.716 . In the chi-square table, the critical value of $95 \%$ confidence interval with 2 degree of freedom is 5.991. It is also observed that the intergroup homogeneity value is smaller than the critical value in the chi-square table ( $\left.\mathrm{Q}_{\mathrm{B}}=5.991, p=.156>.05\right)$. In this regard, it can be stated that the teaching RME-based teaching does not show a significant difference in terms of the level of education.

The results regarding the significant difference between the effect sizes of the studies in terms of sample size (16-30, 31-45, and 46-60 participants) of RME-based teaching are shown in Table 6.

Table 6. Results regarding the effect size in terms of sample size

\begin{tabular}{|c|c|c|c|c|c|c|c|}
\hline \multirow[t]{2}{*}{ Moderator } & \multirow{2}{*}{$\begin{array}{l}\text { Intergroup } \\
\text { Homogeneity } \\
\text { Value } \\
\left(\mathrm{Q}_{\text {в }}\right)\end{array}$} & \multirow[t]{2}{*}{$p$} & \multirow[t]{2}{*}{$\mathrm{n}$} & \multirow{2}{*}{$\begin{array}{l}\text { Overall } \\
\text { Effect } \\
\text { Size } \\
\text { Value } \\
\text { (ES) }\end{array}$} & $\begin{array}{l}\% 95 \\
\text { Interval } \\
\text { Size } \\
\end{array}$ & $\begin{array}{l}\text { Confidence } \\
\text { for Effect }\end{array}$ & $\begin{array}{l}\text { Standard } \\
\text { Error } \\
\text { (SE) }\end{array}$ \\
\hline & & & & & $\begin{array}{l}\text { Lower } \\
\text { Limit }\end{array}$ & $\begin{array}{l}\text { Upper } \\
\text { Limit }\end{array}$ & \\
\hline Sample size $^{*}$ & 0.722 & 0.697 & & & & & \\
\hline $16-30$ participants & & & 25 & 0.735 & 0.618 & 0.851 & 0.059 \\
\hline 31-45 participants & & & 12 & 0.812 & 0.671 & 0.953 & 0.072 \\
\hline 46-60 participants & & & 3 & 0.792 & 0.550 & 1.033 & 0.123 \\
\hline
\end{tabular}

"Only the experimental groups

Three study was not included in the analysis as two of them had 1-15 participants and one of them had 76-90 participants as the sample size. Table 6 shows that intergroup homogeneity value $\left(\mathrm{Q}_{\mathrm{B}}\right)$ in terms of sample size is 0.722 . In the chi-square table, the critical value of $95 \%$ confidence interval with 2 degree of freedom is 5.991. It is also observed that the intergroup homogeneity value is smaller than the critical value in the chi-square table $\left(\mathrm{Q}_{\mathrm{B}}=0.722, p=.697>.05\right)$. In this regard, it can be stated that RME-based teaching does not show a significant difference in terms of sample size. 
The results regarding the significant difference between the effect sizes of the studies in terms of treatment duration (1-5, 6-10, 11-15, and 16-20 hours) of RME-based teaching are shown in Table 7.

Table 7. Results regarding the effect size in terms of treatment duration

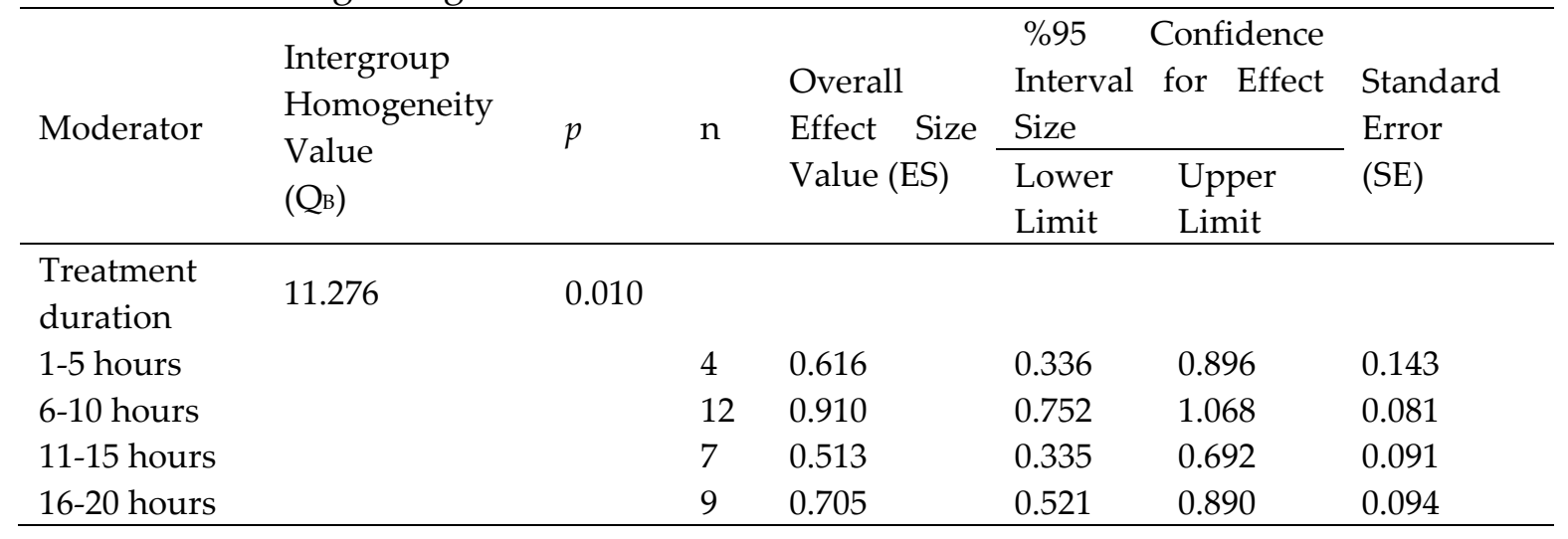

Only one study was determined to have 26-30 hours of treatment, two studies were determined to have 36-40 hours of treatment and seven studies did not specify the hour of treatment and these studies were not included in the analysis. Table 7 reveals that intergroup homogeneity value $\left(\mathrm{Q}_{в}\right)$ in terms of sample size is 11.276 . In the chi-square table, the critical value of $95 \%$ confidence interval with 3 degree of freedom is 7.815 . It is also observed that the intergroup homogeneity value is greater than the critical value in the chi-square table $\left(Q_{B}=11.276, p=.010<0.05\right)$. In this regard, it can be stated that RME-based teaching shows a significant difference in terms of treatment duration. The calculated effect sizes of the groups are medium. However, it can be stated that the effect size of the 6-10 lesson hours is at the large limit, while the effect size of the 11-15 lesson hours is at the weak limit.

\section{Discussion and Conclusion}

This study examining the effects of RME-based teaching on the mathematical achievement of students in Turkey, and a total of 43 effect sizes from 40 studies were examined. It was observed that all the studies had positive values, meaning that RME-based teaching was effective, in favor of the experimental groups. The overall effect size as calculated in accordance with fixed effects model is 0.760 . This value is considered medium according to Cohen et al. (2007). In this regard, it can be stated that the RME-based teaching has a positive effect on the mathematical achievement of students. This finding is in agreement with the findings of Kaplan et al. (2015) (ES=0.607) and Çelik (2013) (ES=0.714) 
whereas the findings of Özdemir (2020) (ES=1.048), and the findings of Tamur, Juandi and Adem (2020) (ES=1.104), reveals that the effect of RME on students' mathematic achievement is large. Inclusion criterias and the number of studies included in the meta-analysis may have been effective in the difference of the research result from Özdemir (2020). Moreover, this finding is also in alignment with the findings of some studies claiming that RME-based teaching has positive effects on the mathematical achievement (Demir, 2017; Fauzan, 2002; Gravemeijer \& Doorman, 1999; Korkmaz, 2017; Le, 2006; Sembiring et al., 2008; Taş, 2018; Yorulmaz, 2018).

In this study, the field of study, level of education, sample size, and treatment duration were specified as the moderators. The purpose of this study is to examine if there was a statistically significant difference in the effect size of RME-based teaching in terms of these moderators. As a result of the analysis of the moderators;

- The effect size values which were calculated in terms of mathematics ( $E S=0.753$ ) and geometry (ES=0.779) fields had a medium level effect (Cohen et al., 2007), and there was no statistically significant difference.

- From the effect size values which were calculated in terms of primary school (ES=0.787), middle school (ES=0.715), and high school (ES=1.013) levels of education, the primary and middle school effect sizes had a medium level effect and high school had large effect, and there was no statistically significant difference.

- The effect size values which were calculated in terms of sample size, 16-30 participants (ES=0.735), 31-45 participants ( $E S=0.812$ ), and 46-60 participants (ES=0.792) had a medium level effect, and there was no statistically significant difference.

- The effect size values which were calculated in terms of treatment duration, 1-5 hours (ES=0.616), 6-10 hours ( $E S=0.910), 11-15$ hours (ES=0.513), 16-20 hours $(E S=0.705)$ had a medium level effect, and there was statistically significant difference. Accordingly, it can be stated that the effect size of the 6-10 lesson hours is at the large limit, while the effect size of the 11-15 lesson hours is at the weak limit. 
This study only examined the effects of RME-based teaching on students' mathematic achievement. Future studies can examine the effects of RME-based teaching on students' attitudes towards mathematics, motivation, reflective thinking skills, creative thinking skills etc. Moreover, the effect of different moderators on the mathematic achievement may also be examined. As a result of the problems arising from the nature of experimental research, meta-analysis studies can also be negatively affected. Uncontrollable factors other than the independent variable may affect the dependent variable. For example, students in the experimental group make an intense effort to show themselves better to their teachers or researcher. It even keeps their anxiety and motivation levels different than normal. This situation may negatively affect the effect values that will appear in meta-analysis studies due to the results obtained from experimental studies. As a matter of fact, the data in the metaanalysis are combined in the light of the results obtained from the experimental studies. The fact that such meta-analysis studies are quantitative here adds a misleading perception to readers and researchers in terms of certainty. For this reason, it should be stated in the conclusion part of the study that caution should be exercised in meta-analysis studies and that the final correct finding cannot be obtained only with these studies. If the data obtained from meta-analysis are supported with qualitative and other quantitative results, it makes better sense. Just as a good meal comes with the combination of ingredients that increase the flavor of that meal.

\section{Acknowledgement}

The data used in this study does not require the approval of Institutional Ethical Review Board.

\section{Authorship Contribution Statement}

Sedat TURGUT: Conceptualization, design of the work, , literature search, data collection, data analysis, data interpretation, writing - review and editing.

\section{References}

The sources marked with an asterisk $\left(^{*}\right)$ indicate studies included in this meta-analysis. *Aksarı, H. (2019). Gerçekçi matematik eğitimine dayalı öğretimin 6. sinı öğrencilerinin matematik başarisina etkisi [The effect of realistic mathematics education on the mathematics achievement of $6^{\text {th }}$ grade students'] (Unpublished master's thesis). Akdeniz University, Antalya. 
*Akyüz, M. C. (2010). Gerçekçi matematik eğitimi (RME) yönteminin ortaöğretim 12. sinıf matematik (integral ünitesi) öğretiminde öğrenci başarısına etkisi [Effect of realistic mathematics education (RME) method on student success in secondary education 12th grade mathematics (integral unit) education] (Unpublished master's thesis). Yüzüncü Yıl University, Van.

*Altaylı, D. (2012). Gerçekçi matematik eğitiminin oran orantı konusunun öğretimi ve orantısal akıl yürütme becerilerinin geliştirilmesine etkisi [The effect of realistic mathematics education on teaching the subject of ratio and proportion and development of proportional reasoning skills] (Unpublished master's thesis). Atatürk University, Erzurum.

*Altıparmak, K., \& Çiftçi, B. (2018). Bilgisayar destekli gerçekçi matematik eğitimi yaklaşımının etkililiği üzerine deneysel bir çalışma [An experimental study on the effectiveness of computer aided realistic mathematics education]. Necatibey Eğitim Fakültesi Elektronik Fen ve Matematik Eğitimi Dergisi, 12(2), 228-253. Doi: 10.17522/balikesirnef.506434

*Altunay, K. (2018). İlkokul 3.sınf öğrencilerinde gerçekçi matematik etkinliklerinin veri öğrenme alanina etkisi [Efficiency of datum learning field of realistic mathematic activities on 3 th grade of primary students] (Unpublished master's thesis). Bayburt University, Bayburt.

*Arseven, A. (2010). Gerçekçi matematik öğretiminin bilişsel ve duyuşsal öğrenme ürünlerine etkisi [Effects of the realistics mathematics teaching on cognitive and affective learning outcomes] (Unpublished doctoral dissertation). Hacettepe University, Ankara.

*Aydın Ünal, Z., \& İpek, A. S. (2009). Gerçekçi matematik eğitiminin ilköğretim 7.sınıf öğrencilerinin tam sayılarla çarpma konusundaki başarılarına etkisi [The effect of realistic mathematics education on 7th grade students' achievements in multiplication of integers]. Ĕ̆itim ve Bilim, 34(152), 60-70.

*Aytekin Uskun, K. (2020). Illkokul dördüncü sınıf öğrencilerinin dört işlem problemlerinde gerçekçi matematik eğitimi yaklaşımının problem çözme ve problem kurma başarılarına etkisinin araştırilması [Investigation of the effect of realistic mathematics education approach on the success of problem solving and problem setting in primary school fourth grade students] (Unpublished master's thesis). Kırşehir Ahi Evran University, Kırşehir.

*Ayvalı, İ. (2013). Gerçekçi matematik eğitimi yaklaşımıyla yapılan öğretimin hesapsal tahmin başarısına ve strateji kullanımına etkisi [The effect of the instruction that is made with realistic mathematics education approach on the computational estimation success and strategy usage] (Unpublished master's thesis). Marmara University, İstanbul.

*Bıldırcın, V. (2012). Gerçekçi matematik eğitimi (GME) yaklaşımın ilköğretim beşinci sınıflarda uzunluk, alan ve hacim kavramlarmm öğretimine etkisi [The effects of the realistic mathematics education (RME) approach in the teaching of the concepts of length, area and volume to the 5th grade primary school students] (Unpublished master's thesis). Ahi Evran University, Kırşehir.

Borenstein, M., Hedges, L. V., Higgins, J. P. T., \& Rothstein, H. R. (2009). Introduction to metaanalysis. UK: John Wiley \& Sons, Ltd., Publications.

*Büyükikiz Kütküt, H. (2017). Gerçekçi matematik eğitimi yaklaşımının ortaokul matematik derslerinde kullanımının incelenmesi ve öğrenci başarısına etkisi [The investigation of using realistic mathematics education (RME) on secondary math lessons and the effects on students' math achievement] (Unpublished master's thesis). Çukurova University, Adana. 
*Can, M. (2012). İlköğretim 3. sınıflarda ölçme konusunda gerçekçi matematik eğitimi yaklaşımının öğrenci başarısına ve öğrenmenin kalıcilı̆̆ına etkisi [A study regarding the effect of realistic mathematics education approach on the success of the students in third grades of primary education on measurement and permanency of acquired knowledge] (Unpublished master's thesis). Abant İzzet Baysal University, Bolu.

*Cengiz, S. (2020). Gerçekçi matematik öğretiminin 5. sınıf öğrencilerinin akademik başarı, motivasyon ve kalıclliklarn üzerindeki etkisi [The effect of realistic mathematics education on academic succes, motivation and retention of $5^{\text {th }}$ grade students] (Unpublished master's thesis). Afyon Kocatepe University, Afyon.

Cohen, L., Manion, L., \& Morrison, K. (2007). Research methods in education. New York: Routledge.

*Çakır, P. (2013). Gerçekçi matematik eğitimi yaklaşımının ilköğretim 4. sınıf öğrencilerinin erişilerine ve motivasyonlarma etkisi [The effect of the instruction based realistic mathematics education on 4th graders achievement and motivation] (Unpublished master's thesis). Dokuz Eylül University, İzmir.

"Çakır, Z. (2011). Gerçekçi matematik eğitimi yönteminin ilköğretim 6. sınıf düzeyinde cebir ve alan konularında öğrenci başarısı ve tutumuna etkisi [The impact of students' success and attitude towards math, carrying out an education supported by RME including 'algebra and field measurement' subject of primary school 6th grades]. (Unpublished master's thesis). Zonguldak Karaelmas University, Zonguldak.

"Çamel, K. (2020). Gerçekçi matematik eğitimi yaklaşımının 12. sınıf üstel ve logaritma fonksiyonları öğretiminde öğrenci başarısına etkisi [The effect of realistic mathematics education approach on student success in teaching $12^{\text {th }}$ grade exponential and logarithm functions] (Unpublished master's thesis). Erciyes University, Kayseri.

Çelik, S. (2013). Illköğretim matematik derslerinde kullanılan alternatif öğretim yöntemlerinin akademik başarıya etkisi: Bir meta analiz çalışması [The effect of alternative teaching methods used in elementary mathematics classes on academic success: A meta analysis study] (Unpublished master's thesis). Eskişehir Osmangazi University, Eskişehir.

*Çilingir Altıner, E., \& Dinç Artut, P. (2017). İlkokulda gerçekçi matematik eğitimi ile gerçekleştirilen öğretimin öğrencilerin başarısına, görsel matematik okuryazarlığına ve problem çözme tutumlarına etkisi [The effect of instruction based realistic mathematics education on elementary students' avhievement, visual mathematic literacy and problem solving attitude]. Marmara Üniversitesi Atatürk Ĕ̆itim Fakültesi Ĕ̆itim Bilimleri Dergisi, 46, 1-19. DOI: 10.15285/maruaebd.279963

*Çilingir, E., \& Dinç Artut, P. (2016). Gerçekçi matematik eğitimi yaklaşımının ilkokul öğrencilerinin başarılarına, görsel matematik okuryazarlığı özyeterlik algılarına ve problem çözme tutumlarına etkisi [Effect of realistic mathematics education approach on visual mathematics literacy perceptions and problem solving attitude of students]. Turkish Journal of Computer and Mathematics Education, 7(3), 578-600. https://dx.doi.org/10.16949/turkbilmat.277872

De Corte, E. (2000). Fostering cognitive growth. A perspective from research on mathematics learning and instruction. In P. K. Smith, \& A. D. Pellegrini (Eds.), Psychology of education major themes (pp. 251-270). London: Routledge Falmer.

De Lange, J. (1987). Mathematics, insight and meaning. Utrecht, the Netherlands: OW \& OC, Utrecht University. 
Demir, G. (2017). Gerçekçi matematik eğitimi yaklaşımının meslek lisesi öğrencilerinin matematik kaygisına, matematik özyeterlik algisına ve başarısına etkisi [The effect of realistic mathematics education approach on mathematical anxiety, mathematical self-efficacy perceptions and achievement of vocational high school students] (Unpublished master's thesis). Adnan Menderes University, Aydin.

*Demirdöğen, N., \& Kaçar, A. (2010). İlköğretim 6. sinıfta kesir kavramının öğretiminde gerçekçi matematik eğitimi yaklaşımının öğrenci başarısına etkisi [The effect of realistic mathematics education approach on the student's success of teaching fraction concept in 6th class]. Erzincan Eğitim Fakültesi Dergisi, 12(1), 57-74.

Di Martino, P., \& Zan, R. (2011). Attitude towards mathematics: A bridge between beliefs and emotions. ZDM Mathematics Education, 43(4), 471-482. https://doi.org/10.1007/s11858-011-0309-6

"Dönmez, P. (2018). The effect of using realistic mathematics education on the 7th grade students' mathematical achievement about algebraic expression and attitude towards mathematics [Gerçekçi matematik eğitiminin 7. sını öğrencilerinin cebirsel ifadelerdeki matematik başarısına ve ögrrencileri matematiğge dair tutumlarna etkisi] (Unpublished master's thesis). Yeditepe University, İstanbul.

Ellis, P. D. (2010). The essential guide to effect sizes. Statistical power, meta-analysis, and the interpretation of research result. New York: Cambridge University Press.

"Erdoğan, H., \& Ayvaz-Tuncel, Z. (2018). Gerçekçi matematik eğitimine dayalı matematik öğretiminin akademik başarı, kalıcılık ve yansıtıcı düşünme becerisi üzerine etkisi [The effect of realistic mathematics education activities on students' achievement, retention levels and reflective thinking skills]. Turkish Studies, 13(19), 653-668. http://dx.doi.org/10.7827/TurkishStudies.13943

"Ersoy, E. (2013). Gerçekçi matematik eğitimi destekli öğretim yönteminin 7. sınıf olasılık ve istatistik kazanımlarının öğretiminde öğrenci başarısına etkisi [The effect of teaching method supported with realistic mathematic education on teaching probablity and statistic goals on seventh grade] (Unpublished master's thesis). Sakarya University, Sakarya.

Fauzan, A. (2002). Applying realistic mathematics education (RME) in teaching geometry in Indonesian primary schools (Doctoral dissertation). The Netherlands, Enschede: University of Twente.

Freudenthal, H. (1971). Geometry between the devil and the deep sea. Educational Studies in Mathematics, 3(3/4), 413-435. Retrieved from http://www.jstor.org/stable/3482035

Freudenthal, H. (1973). Mathematics as an educational task. Dordrecht: Reidel.

Freudenthal, H. (1991). Revisiting mathematics education. China lectures. The Netherlands, Dordrecht: Kluwer Academic.

Glass, G. V. (1976). Primary, secondary, and meta-analysis of research. Educational Researcher, 5(10), 3-8. https://doi.org/10.3102/0013189X005010003

*Gözkaya, Ş. (2015). Gerçekçi matematik eğitimi destekli öğretim yönteminin 7. sinıf oran-orantı konularının öğretiminde öğrenci başarısına ve öğrenmenin kalıcılı̆̆ına etkisi [The effect of realistic mathematic education supported instruction method on seventh grade students' achievement and retention levels in ratio and proportion topics] (Unpublished master's thesis). Erciyes University, Kayseri.

Gravemeijer, K. (1994). Developing realistic mathematics education (Doctoral dissertation). Utrecht: CD $\beta$-Press/Freudenthal Institute. 
Gravemeijer, K., \& Doorman, M. (1999). Context problems in realistic mathematics education: A calculus course as an example. Educational Studies in Mathematic, 39, 111129. https://doi.org/10.1023/A:1003749919816

Gravemeijer, K., \& Terwel, J. (2000). Hans Freudenthal: A mathematician on didactics and curriculum theory. Journal of Curriculum Studies, 32(6), 777- 796. https://doi.org/10.1080/00220270050167170

Harrer, M., Cuijpers, P., Furukawa, T. A., \& Ebert, D. D. (2019). Doing meta-analysis in R: A hands-on guide. doi:10.5281/zenodo.2551803. https://bookdown.org/MathiasHarrer/Doing_Meta_Analysis_in_R/

Hunter, J. E., \& Schmidt, F. L. (2004). Methods of meta-analysis. Correcting error and bias in research findings. Thousand Oaks, CA: Sage publications.

*Işık, S. (2019). Diziler konusunun gerçekçi matematik eğitimi etkinlikleriyle öğretiminin öğrenci başarısına matematik tutumuna etkisi ve öğrenci görüşlerinin incelenmesi [The effects of teaching sequences with realistic math education activities on student achievement, mathematics attitude and investigation of student opinions] (Unpublished doctoral dissertation). İnönü University, Malatya.

*Işıtan, H., \& Doğan, M. (2018). Gerçekçi matematik eğitiminin tam sayılar konusundaki başarı ve kalıcılığa etkisi [The effect of realistic mathematics education on achievement and recall in integers]. Medeniyet Eğitim Araştırmaları Dergisi, 1(4), 1-9.

Kaplan, A., Duran, M., Doruk, M., \& Öztürk, M. (2015). Gerçekçi matematik eğitimi destekli öğretimin matematik başarısına etkisi: Bir meta-analiz çalışması [Effects of instruction based on realistic mathematics education on mathematics achievement: A metaanalysis study]. International Journal of Human Sciences, 12(2), 187-206. https://doi.org/10.14687/ijhs.v12i2.3300

"Karadöl, D. (2019). Gerçekçi matematik eğitimi destekli öğretim yönteminin 6. sinıf alan ölçme konusunun öğretiminde öğrenci başarısına ve öğrenme kalıcllı̆̆ına etkisi [The impact of realistic mathematics instruction method on the student achievement and retention of learning in the teaching of $6^{\text {th }}$ grade area measurement subject] (Unpublished master's thesis). Erciyes University, Kayseri.

*Karataş, D. (2019). Ondalık gösterimler konusunun ortaokul 5. sınıf öğrencilerinde gerçekçi matematik eğitimiyle öğretiminin başarrya etkisi [The effect of decimal representation on the achievement of realistic mathematics education in secondary school $5^{\text {th }}$ grade students] (Unpublished master's thesis). Gazi University, Ankara.

"Kaylak, S. (2014). Gerçekçi matematik eğitimine dayalı ders etkinliklerinin öğrenci başarısına etkisi [Effects of realistic mathematics education activities on students' achievement] (Unpublished master's thesis). Necmettin Erbakan University, Konya.

Korkmaz, E. (2017). Dönüşüm geometrisi konularmın gerçekçi matematik eğitimi (GME) etkinlikleriyle işlenmesinin öğrenci başarısına ve matematik tutumuna etkisi [The effect of processing transformation geometry topics with realistic mathematics education (RME) activities on students' success and mathematics attitude] (Unpublished doctoral dissertation). İnönü University, Malatya.

"Korkmaz, E., \& Korkmaz, C. (2017). Ebob-Ekok konusunun gerçekçi matematik eğitimi etkinlikleriyle öğretiminin başarı ve tutuma etkisi [Ebob-Ekok subject effect to success and attitude with teaching realistic mathematics education activities]. Mustafa Kemal Üniversitesi Sosyal Bilimler Enstitüsü Dergisi, 14(39), 504-523. 
"Korkmaz, E., \& Tutak, T. (2017). Dönüşüm geometrisi konularının gerçekçi matematik eğitimi etkinlikleriyle işlenmesinin öğrenci başarısına ve matematik tutumuna etkisi [The effects on student success and mathematics attitude of teaching the subject of transitional geometry with realistic mathematics education activities]. Disiplinlerarası Ĕ̆itim Araştırmaları Dergisi 1(2), 30-42.

"Kurt, E. S. (2015). Gerçekçi matematik eğitimi'nin uzunluk ölçme konusunda başarı ve kalıchlı̆̆a etkisi [The effect of realistic mathematics education on achievement and recall in lenght measurement] (Unpublished master's thesis). Ondokuz Mayıs University, Samsun.

Le, T. A. (2006). Applying realistic mathematics education in Vietnam: Teaching middle school geometry (Doctoral dissertation). Potsdam: Mathematisch-Naturwissenschaftlichen Fakultät der Universität Potsdam.

Lipsey, M. W., \& Wilson, D. B. (2001). Practical meta-analysis. Thousand Oaks, CA: Sage publications.

Mertens, D. M. (2010). Research and evaluation in education and psychology: Integrating diversity with quantitative, qualitative, and mixed methods. USA: Sage publications.

Mullen, B., Muellerleile, P., \& Bryant, B. (2001). Cumulative meta-analysis: A consideration of indicators of sufficiency and stability. Personality and Social Psychology Bulletin, 27(11), 1450-1462. https://doi.org/10.1177/01461672012711006

"Nama Aydın, G. (2014). Gerçekçi matematik eğitiminin ilkokul 3. sınıf öğrencilerine kesirlerin öğretiminde başarrya kahıcılı̆̆a ve tutuma etkisi [Effect of realistic mathematics education in teaching fractions to the third grade primary school students on achievement, retention and attitude] (Unpublished master's thesis). Abant İzzet Baysal University, Bolu.

National Council of Teachers of Mathematics. (2000). Principles and standards for school mathematics. Reston, VA: NCTM.

*Okuyucu, M. A., \& Bilgin, T. (2019). Gerçekçi matematik eğitiminin veri, sayma ve olasılık öğretiminde öğrenci başarısına etkisi ve öğretime yönelik öğrenci görüşleri [The effect of realistic mathematics education on student achievement in data, counting and probability teaching and student opinions towards instruction]. International Journal of Educational Studies in Mathematics, 6(3), 79-107.

Organization for Economic Co-operation and Development [OECD]. (2013). PISA 2012 assessment and analytical framework: Mathematics, reading, science, problem solving and financial literacy. Paris: OECD Publishing. Retrieved from http://dx.doi.org/10.1787/9789264190511-en

*Özçelik, A., \& Tutak, T. (2017). 7. sınıf yüzde ve faiz konusunun gerçekçi matematik eğitimine dayalı olarak işlenmesinin öğrencilerin başarı ve tutumlarına etkisi [The effect of teaching the subject of percentages and interest in 7th grade based on realistic mathematics education on students' achievement and attitude]. Elektronik Eğitim Bilimleri Dergisi, 6(12), 204-2015.

*Özdemir, E., \& Üzel, D. (2011). Gerçekçi matematik eğitiminin öğrenci başarısına etkisi ve öğretime yönelik öğrenci görüşleri [The effect of realistic mathematics education on student achievementand student opinions towards instruction]. H. Ü. Eğitim Fakültesi Dergisi (H. U. Journal of Education), 40, 332-343.

Özdemir, Z. B. (2020). Türkiye'de gerçekçi matematik eğitiminin matematik başarısına etkisi üzerine bir meta analiz çalışması [A meta-analysis study on the effect of mathematics achievement on 
realistic mathematics education in Turkey] (Unpublished master's thesis). Marmara University, İstanbul.

*Özkaya, A., \& Yetim Karaca S. (2017). The effects of realistic mathematics education on students' achievements and attitudes in fifth grades mathematics courses. International Online Journal of Education and Teaching (IOJET), 4(2). 185-197. http://iojet.org/index.php/IOJET/article/view/187/162

*Özkürkçüler, L. (2019). Gerçekçi matematik eğitimine dayalı öğretimin 4.sinı öğrencileri üzerindeki etkileri [Effects of realistic mathematics education based instruction on $4^{\text {th }}$ grade students] (Unpublished master's thesis). Aydın Adnan Menderes University, Aydın.

Pigott, T. (2012). Advances in meta-analysis. New York: Springer Science \& Business Media.

Piht, S., \& Eisenschmidt, E. (2008). Pupils' attitudes toward mathematics: Comparative research between Estonian and Finnish practice schools. Problems of Education in the 21st Century, 9, 97-106.

Rosenthal, R. (1991). Meta-analytic procedures for social research. California: Sage Publication.

Rothstein, H. R., Sutton, A. J., \& Borenstein, M. (Eds.). (2005). Publication bias in meta-analysis: Prevention, assessment and adjustments. Chichester, UK: John Wiley \& Sons.

Sánchez-Meca, J., \& Marín-Martínez, F. (2010). Meta analysis. In P. Peterson, E. Baker, \& B. McGaw (Eds.), International encyclopedia of education (Vol. 7, pp. 274-282). Oxford: Elsevier.

Sembiring, R. K., Hadi, S., \& Dolk, M. (2008). Reforming mathematics learning in Indonesian classrooms through RME. ZDM Mathematics Education, 40(6), 927-939. https://doi.org/10.1007/s11858-008-0125-9

Soric, I., \& Palekcic, M. (2009). The role of students' interest in self-regulated learning: The relationship between students' interests, learning strategies and causal attributions. European Journal of Psychology of Education, 24(4), 545-565.

Tamur, M., Juandi, D., \& Adem, A. M. G. (2020). Realistic mathematics education in Indonesia and recommendations for future implementation: A meta-analysis study. JTAM (Jurnal Teori dan Aplikasi Matematika), 4(1), 17-27. https://doi.org/10.31764/jtam.v4i1.1786

Taş, T. E. (2018). Gerçekçi matematik eğitimi destekli öğretim yönteminin ilköğretim 6. sınıf öğrencilerinin matematik başarılarma ve tutumlarma etkisi [The effects of realistic mathematics educations on 6 th grade students' achievements] (Unpublished master's thesis). Çukurova University, Adana.

Treffers, A. (1978). Wiskobas doelgericht [Wiskobas goal directed]. IOWO, Utrecht.

Treffers, A. (1987). Three dimensions: A model of goal and theory description in mathematics-The Wiskobas Project. Dordrecht, The Netherlands: Reidel.

Treffers, A. (1991). Didactical background of a mathematics program for Primary Education. In L. Streefland (Ed.), Realistic mathematics education in primary schools (pp. 21-56). Utrecht: CD $\beta$-Press/Freudenthal Institute.

Treffers, A. (1993). Wiskobas and Freudenthal realistic mathematics education. In L. Streefland (Ed.) The legacy of Hans Freudenthal (pp. 89-108). Dordrecht: Springer.

"Uygur, S. (2012). 6. sinıf kesirlerle çarpma ve bölme işlemlerinin öğretiminde gerçekçi matematik eğitiminin öğrenci başarısına etkisi [The effect of realistic mathematics education on 6 th grade students' achievements in teaching of the division and multiplication operations with fractions] (Unpublished master's thesis). Atatürk University, Erzurum. 
*Üzel, D. (2007). Gerçekçi matematik eğitimi (RME) destekli eğitimin ilköğretim 7. sinıf matematik ögrretiminde öğrenci başarısına etkisi [The effect of the education supported by realistic mathematics education on student achievement in mathematics teaching of primary school 7 th class] (Unpublished doctoral dissertation). Balıkesir University, Balıkesir.

Van den Heuvel-Panheuizen, M. (2003). The didactical use of models in realistic mathematics education: An example from a longitudinal trajectory on percentage. Educational Studies in Mathematics, 54(1), 9-35. https://doi.org/10.1023/B:EDUC.0000005212.03219.dc

Van den Heuvel-Panhuizen, M. (2001). Realistic mathematics education as work in progress. In F. L. Lin (Ed.), Common sense in mathematics education. Proceedings of 2001 The Netherlands and Taiwan Conference on Mathematics Education (pp. 1-43). Taipei, Taiwan: National Taiwan Normal University.

Van den Heuvel-Panhuizen, M., \& Drijvers, P. (2014). Realistic mathematics education. In S. Lerman (Ed.), Encyclopedia of mathematics education (pp. 521-525). Dordrecht: Springer Science+Business Media.

"Yonucuoğlu, A. (2018). Gerçekçi matematik eğitiminin ortaokul 7. sinı öğrencilerinin dörtgenlerde alan konusundaki matematiksel başarlarna ve motivasyonlarna etkisi [The effects of realistic mathematics education on $7^{\text {th }}$ grade students' achievements and motivations in area of quadrilaterals] (Unpublished master's thesis). Gaziantep University, Gaziantep.

Yorulmaz, A. (2018). Gerçekçi matematik eğitiminin ilkokul dördüncü sınıf öğrencilerinin dört işlem becerilerindeki hatalarmm giderilmesine etkisi [The impact of realistic mathematics education on correcting the mistakes in number operations skills of fourth grade primary school students] (Unpublished doctoral dissertation). Marmara University, İstanbul. 